\title{
PKM KERAJINAN “BALI GOOD” PATUNG LIMBAH PANTAI DI DESA BLAHBATUH KABUPATEN GIANYAR
}

\author{
*Putu Yudha Asteria Putri ${ }^{1}$, I Gusti Ayu Ratih Permata Dewi ${ }^{2}$, I Gede Nyoman Carlos W \\ Mada $^{3}$
}

1,2,3 Fakultas Ekonomi dan Bisnis Universitas Warmadewa

*Email: ydhasteria.putri@gmail.com

\begin{abstract}
The management of "Bali Good Sculpture" has not been done well, in the sense that it is still done conventionally. Financial bookkeeping is not yet owned so the owner / craftsman does not know accurately the magnitude of the profits and the amount of costs spent in the production and operational processes. The marketing pattern of "Bali Good" Beach Waste Sculpture relies on information from its blog but the information has never been updated. Surely this will have an impact on the information conveyed on the blog not in accordance with current conventions, both regarding price information, products or correspondence that can be contacted. The showroom from "Bali Good Patung" still seems quite narrow and uncomfortable for customers who want to see the display of the statue they have. The basic contribution of this program is to improve the quality of human resources, increase production capacity, marketing through the website, turnover and company assets.
\end{abstract}

Keywords : PKM, Beach Waste Sculpture

\begin{abstract}
ABSTRAK
Pengelolaan "Bali Good Patung" belum dilakukan secara baik, masih dilakukan secara konvensional. Pembukuan keuangan belum dimiliki sehingga pemilik/pengrajin tidak mengetahui secara akurat besaran keuntungan yang didapatkan dan besaran biaya yang dihabiskan dalam proses produksi dan operasional. Tenaga kerja yang dimiliki oleh bapak I Made Darsana sebanyak 8 orang yang berasal dari orang-orang sekitar rumahnya. Pola pemasaran "Bali Good" Patung Limbah Pantai mengandalkan informasi dari blog yang dimiliki tetapi informasinya tidak pernah di update oleh pemiliknya karena keterbatasan kemampuan dan pemahaman dalam mengoperasikannya. Tentunya hal ini akan berdampak pada informasi yang disampaikan di blog tidak sesuai dengan konsidi kekinian, baik menyangkut informasi harga, produk ataupun korespondensi yang bisa dihubungi. Showroom dari "Bali Good Patung" masih terkesan cukup sempit dan kurang nyaman bagi pelanggan yang ingin melihat pajangan patung yang dimilikiKhalayak sasaran dari program pengabdian masyarakan ini adalah "Bali Good Patung" yang terletak di Desa Bedulu Kecamatan Blahbatuh Kabupaten Gianyar Provinsi Bali. Kontribusi dasar dari program ini adalah meningkatkan kapasitas produksi, peningkatan pemasaran melalui website, peningkatan kualitas SDM, peningkatan omset dan asset perusahaan.
\end{abstract}

\section{Kata Kunci : PKM, Patung Limbah Pantai}

\section{PENDAHULUAN}

Salah satu keindahan yang menjadi daya tarik wisatawan baik wisatawan lokal maupun asing adalah indahnya pantai yang ada di Bali. Bali terkenal dengan banyaknya pantai yang indah yang mampu membuat wisatawan berlomba-lomba menikmati keindahan 
pantai tersebut. Namun dewasa ini banyak pantai yang sudah terkontaminasi dengan adanya limbah pantai yang membuat nilai keindahannya berkurang. Limbah pantai dapat berasal dari pesisir pantai yang merupakan sisa dari berbagai macam bentuk hasil laut, seperti limbah dari cangkang kerang laut, sisik dari ikan, tulang ikan yang telah dimakan, tempurung dari kelapa yang telah dibuka, sabut kelapa yang dimana dibuang begitu saja, daun kelapa yang telah tua dan berjatuhan, hewan laut yang sudah mati dan kemudian terdampar di daerah pantai, cangkang dari kepiting dan juga berbagai macam bentuk dari limbah lainnya hingga terumbu karang yang terbawa arus ke pesisir pantai. Limbah pantai umumnya dipandang sebelah mata oleh masyarakat karena dianggap tidak dapat dipergunakan kembali, namun berbeda dengan seorang seniman patung yang dapat mengubah limbah pantai menjadi barang komersial yang mempunyai nilai jual tinggi.

Bali Good didirikan oleh Bapak I Made Darsana dan Istrinya Ibu Ni Ketut Ernawati sejak 22 April 2010, terletak di Desa Bedulu Kecamatan Blahbatuh Kabupaten Gianyar . Beliau belajar membuat patung dari limbah pantai secara otodidak, yang awal mulanya hanya sebuah hobi menjadi sebuah karya seni yang memiliki nilai intrinsic yang tinggi

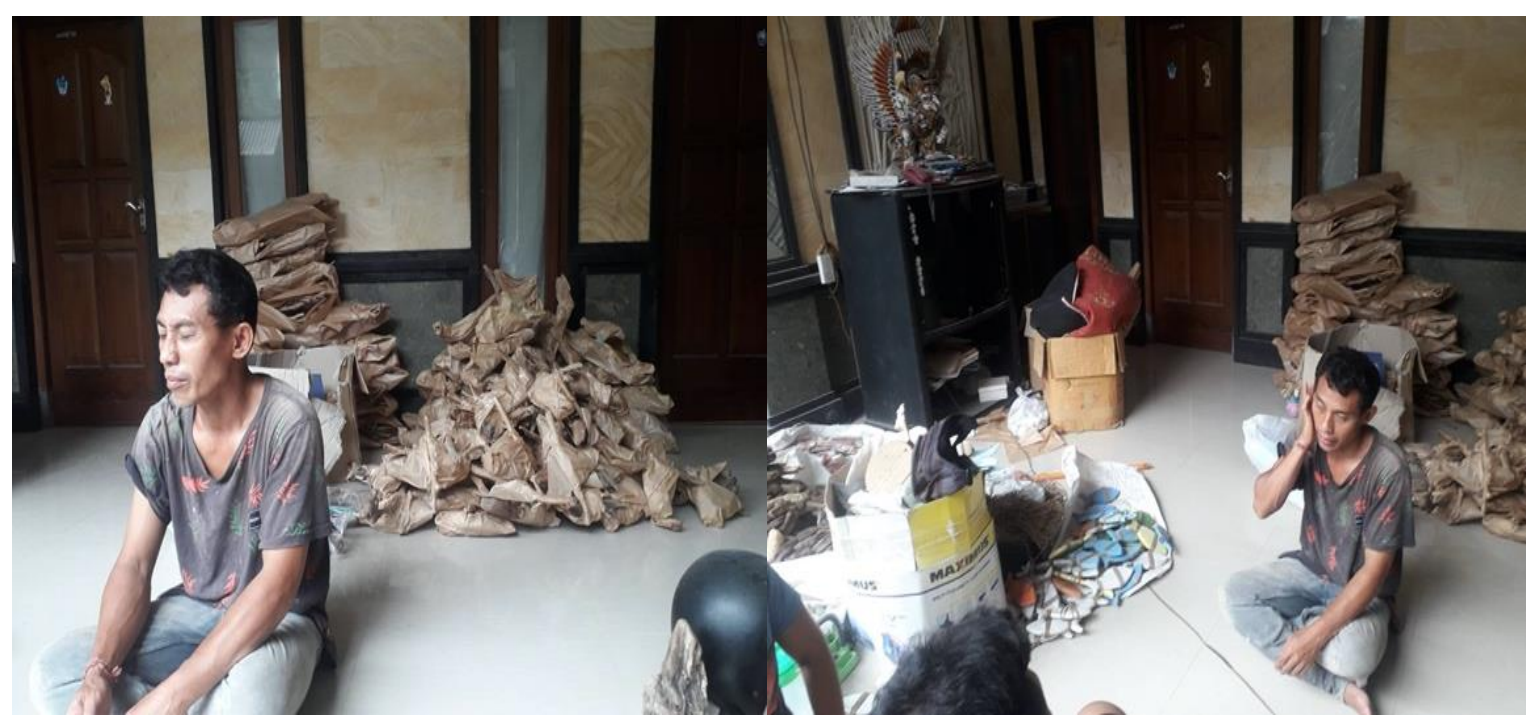

\section{Gambar 1. Profil I Made Darsana}


Tabel 1. Profil I Made Darsana

\begin{tabular}{|l|l|}
\hline \multicolumn{1}{|c|}{ Keterangan } & \multicolumn{1}{c|}{$\begin{array}{c}\text { Mitra 1 } \\
\text { Bali Good Patung }\end{array}$} \\
\hline Nama Pemilik & I Made Darsana \\
\hline Nama UMKM & Bali Good Patung \\
\hline Jenis Usaha & Kerajinan Patung Limbah Pantai \\
\hline Alamat & Br. Taman Desa Bedulu Kec Blahbatuh Gianyar \\
\hline Rata-rata Penjualan per bulan & 3-10 unit \\
\hline Rata-rata pendapatan per bulan & 25.000.000,- \\
\hline Rata-rata Produksi per bulan & 3-10 unit \\
\hline Pangsa Pasar & Lokal dan Nasional \\
\hline Jumlah Tenaga Kerja & 8 orang \\
\hline
\end{tabular}

Ukuran patung limbah pantai yang dibuat mulai dari hanya $15 \mathrm{~cm}$ sampai dengan 2 meter (termasuk dudukan patung). Patung dari limbah pantai ada berbagai macam bentuk, mulai dari ikan, patung dewa, burung, dan masih banyak lagi tergantung bentuk dari limbah tersebut. Limbah pantai yang dipakai bisa berupa batu batuan, kayu, kulit kerang dan limbah pantai lainnya. Limbah pantai sebagai bahan baku kerajinan ini berasal dari sekitar pantai yang ada di Kabupaten Gianyar, yaitu mulai dari Pantai Lebih, Pantai Siyut, Pantai Masceti, Pantai Ketewel, Pantai Pering, Pantai Saba, hingga pantai yang ada di daerah Klungkung. Jika bahan baku tidak ada di pantai sekitaran Gianyar, Pak I Made Darsana mengambil limbah pantai ke daerah Negara.
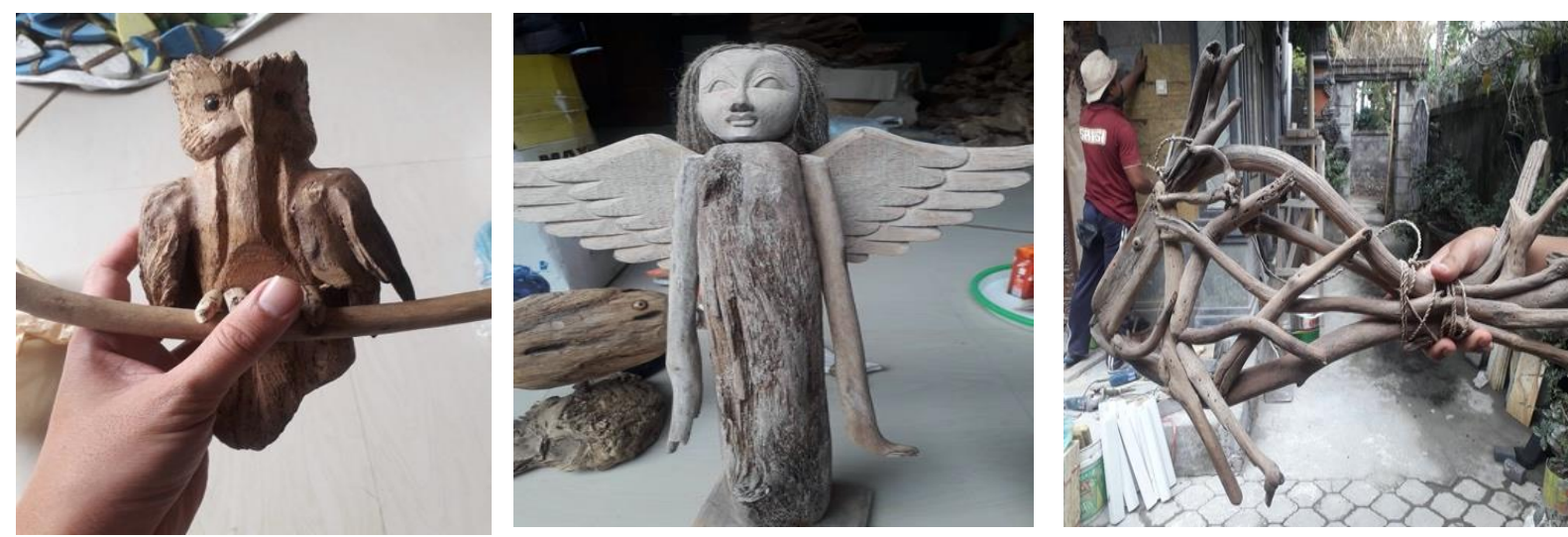

Gambar 2. Hasil Karya Patung Limbah Pantai Karya I Made Darsana

Bentuk dari patung mengikuti bentuk awal dari limbah pantai, lalu di pahat dan dirangkai sehingga menjadi bentuk patung yang bernilai jual tinggi. Bapak I Made Darsana saat ini mempekerjakan 8 orang pegawai yang berasal dari sekitar rumahnya yang masih 
satu "banjar" untuk memproduksi patung limbah pantai. Dimana pengrajin tersebut diberikan pelatihan terlebih dahulu sebelum memproduksi patung.
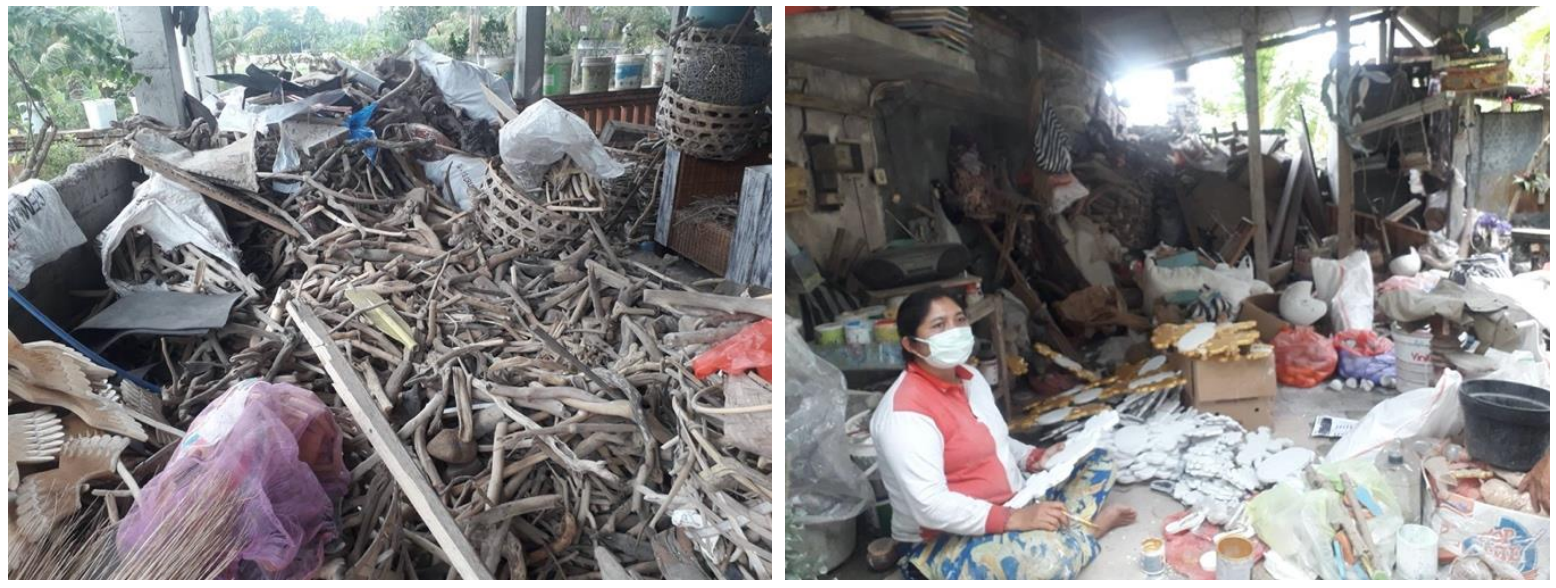

Gambar 3. Bahan baku produksi dari limbah Pantai

Proses pembuatan patung limbah pantai itu sendiri memakan waktu 1 bulan untuk patung setinggi 1 meter, 2 bulan untuk yang tingginya 1,5 meter dan 3 bulan untuk patung yang tingginya 2 meter. Untuk patung-patung kecil hanya membutuhkan waktu 1 minggu untuk menyelesaikannya. Alat-alat yang digunakan dalam proses pembuatan patung limbah pantai meliputi: compressor, bor, mesin sensor, gerinda, mesin jigsaw, amplas dan alat-alat pahat. Harga jual 1 buah patung limbah pantai ukuran sedang (tinggi 1 meter) berkisar 7-10 juta rupiah.Sedangkan yang kecil seharga 500ribu hingga 5 juta rupiah per buahnya.

Pengelolaan "Bali Good Patung" belum dilakukan secara baik, dalam arti masih dilakukan secara konvensional. Pembukuan keuangan belum dimiliki sehingga pemilik/pengrajin tidak mengetahui secara akurat besaran keuntungan yang didapatkan dan besaran biaya yang dihabiskan dalam proses produksi dan operasional. Tenaga kerja yang dimiliki oleh bapak I Made Darsana sebanyak 8 orang yang berasal dari orang-orang sekitar rumahnya. Pola pemasaran "Bali Good" Patung Limbah Pantai mengandalkan informasi dari blog yang dimiliki tetapi informasinya tidak pernah di update oleh pemiliknya karena keterbatasan kemampuan dan pemahaman dalam mengoperasikannya. Tentunya hal ini akan berdampak pada informasi yang disampaikan di blog tidak sesuai dengan konsidi kekinian, baik menyangkut informasi harga, produk ataupun korespondensi yang bisa dihubungi. Showroom dari "Bali Good Patung" masih terkesan cukup sempit dan kurang nyaman bagi pelanggan yang ingin melihat pajangan patung yang dimiliki. Berdasarkan 
observasi yang telah dilakukan terhadap pengrajin patung limbah pantai tersebut, demi keberlanjutan dan eksistensinya sangat layak untuk mendapatkan pembinaan dan bantuan dari pemerintah dalam hal ini Ristekdikti melalui Perguruan Tinggi secara berkesinambungan sehingga dapat meningkatkan kapasitas dan kualitas produk yang terkait dengan pelestarian produk kesenian limbah pantai, pembinaan dan pembenahan manajemen, pemasaran dan aspek lainnya yang saling berkaitan.

Berkaitan dengan pengelolaan manajemen mitra, maka dapat dideskripsikan kondisi masing-masing mitra tersebut:

1. Manajemen pengelolaan mitra tidak dilakukan secara professional karena dikelola secara kekeluargaan. Demikian halnya terkait pembukuan seperti buku harian, buku kas, perhitungan biaya produksi, perhitungan keuntungan atau kerugian belum tersedia dengan baik. Berkaitan dengan pengelolaan SDM masih terlihat tidak jelas dimana pembagian pekerjaan belum jelas antara satu dengan yang lainnya.

2. Mitra belum memiliki sistem promosi yang baik dalam memasarkan produknya. "Bali Good Patung" sudah memiliki blog sendiri tetapi tidak pernah diupdate karena keterbatasan pengetahuan dan kemampuan yang dimiliki oleh pemilik.

3. Pengelolaan persediaan bahan baku limbah pantai kurang baik sehingga mitra harus mencari bahan baku hingga ke kebupaten Negara yang memakan waktu kurang lebih 4 jam perjalanan dari lokasi mitra dan menghambat produksi karena jumlah pekerja yang terbatas.

4. Fasilitas yang dimiliki oleh "Bali Good Patung" meliputi showroom yang berukuran 3 x 3 meter, sejumlah peralatan mulai dari compressor, bor, mesin sensor, gerinda, mesin jigsaw, amplas dan alat-alat pahat.

Berdasarkan hasil observasi pada mitra, terdapat beberapa permasalahan yang menjadi kendala meliputi:

1. Dalam hal akuntansi manajemen, belum memiliki pembukuan untuk menghitung laba rugi, harga pokok produksi dan pencatatan asset yang dimilki.

2. Dalam hal produksi, mitra belum memiliki SOP, baik terkait bahan baku (limbah pantai) maupun alur di dalam proses produksinya. Peralatan yang dimiliki sudah habis umur ekonomisnya sehingga sering mengalami kerusakan seperti mesin serut, bor 
duduk, mesin sensor, gerinda, mesin jigsaw, dan alat-alat pahat serta kesulitan untuk memenuhi kebutuhan bahan baku limbah pantai

3. Dalam hal pemasaran, mitra melakukan pemasaran hanya dengan blog dan tidak pernah dilakukan update informasi dari "Bali Good Patung" dan belum memiliki katalog produk sehingga susah didalam melakukan promosi.

Tujuan program ini dilaksanakan adalah membantu mitra dalam hal "Bali Good Patung" untuk mengatasi permasalahan yang dihadapi berkaitan dengan pengembangan usahanya. Dari permasalahan yang berhasil diidentifikasi, maka solusi penyelesaian masalah yang ditawarkan secara bertahap selama tiga tahun adalah seperti pada Tabel 2 berikut ini:

Tabel 2. Solusi Penyelesaian Masalah

\begin{tabular}{|c|l|l|}
\hline Tahun 1 & \multicolumn{1}{|c|}{ Indikator Capaian } & \multicolumn{1}{|c|}{ Solusi yang Ditawarkan } \\
\hline 1 & $\begin{array}{l}\text { Mitra memiliki gambaran yang jelas tentang } \\
\text { hasil operasionalnya dan mengetahui harga } \\
\text { dasar dari produksi. }\end{array}$ & $\begin{array}{l}\text { Pembentukan dan perancangan } \\
\text { sistem pembukuan baik laba rugi } \\
\text { dan harga pokok produksi }\end{array}$ \\
\hline 2 & $\begin{array}{l}\text { Mitra mengetahui standard bahan baku yang } \\
\text { akan diproduksi }\end{array}$ & $\begin{array}{l}\text { Penyusunan SOP dalam } \\
\text { pembelian bahan baku (limbah } \\
\text { pantai) dan alur proses produksi }\end{array}$ \\
\hline 3 & $\begin{array}{l}\text { Sarana produksi melalui website dan media } \\
\text { sosial lainnya }\end{array}$ & $\begin{array}{l}\text { Pembuatan strategi promosi / } \\
\text { pemasaran melalui pembuatan } \\
\text { website }\end{array}$ \\
\hline
\end{tabular}

\section{METODE PELAKSANAAN}

Berdasarkan permasalahan yang telah disampaikan sebelumnya pada mitra, maka hal-hal yang akan dilakukan selama kegiatan meliputi:

1. Pendampingan dan membantu dalam pembuatan pembukuan dan laporan keuangan sederhana.

2. Melakukan pendampingan dan memberikan pelatihan akuntansi manajemen.

3. Memberikan pelatihan mengenai penerapan tata kelola perusahaan terutama berkaitan dengan penentuan strategi produksi maupun pemasaran.

4. Membuatkan sosial media untuk membantu dalam pemasaran produk serta melakukan pendampingan dalam penggunaannya.

Selain itu mitra juga diberikan sosialisasi mengenai Rumah Kreatif BUMN oleh Bank Rakyat Indonesia yang terletak di Kabupaten Gianyar. Rumah Kreatif BUMN (RKB) membimbing dan mendampingi para pelaku UMKM dalam menghadapi tantangan 
pengembangan usahanya. Pendampingan biasanya dilakukan dalam bentuk peningkatan kompetensi, akses pemasaran, dan kemudahan akses permodalan. Selain membantu permodalan, RKB BRI juga kerap mengadakan pelatihan yang mampu meningkatkan kompetensi para pelaku UMKM sesuai bidangnya masing-masing.

\section{HASIL DAN PEMBAHASAN}

Berikut ini capaian pelaksanaan kegiatan sesuai dengan yang diprioritaskan pada masing-masing mitra, yaitu:

1. Pemberian pendampingan dan pelatihan pembukuan sederhana, menjelaskan pencatatan sederhana harian, mingguan sampai bulanan. Bagaimana cara mencatat biaya - biaya produksi dan mencatat penjualan. Memisahkan keuangan pribadi dengan keuangan hasil usaha, sehingga dapat melihat keuntungan usaha secara jelas dan diharapkan nantinya dapat menyisihkan laba untuk investasi.

2. Pendampingan dan memberikan pelatihan akuntansi manajemen, dimana mitra dijelaskan mengenai rincian biaya produksi, harga pokok, biaya overhead yang dapat dibayarkan untuk menunjang kegiatan operasional dalam aktifitas bisnisnya.

3. Pelatihan mengenai penerapan strategi pemasaran, dimana membantu mitra dalam membuat sosial media yang dapat membantu dalam proses pemasaran produk dan memperkenalkan produk bukan hanya ke konsumen lokal Bali saja tapi kepada konsumen luar Bali sebagai alternatif oleh-oleh khas daerah Gianyar Bali. Selain itu juga saat ini sedang terjadi wabah Covid-19 yang mengharuskan masyarakat bekerja dari rumah. Karya seni yang dibuat oleh Bapak I Made Darsana ini dapat memberikan alternative untuk menghias rumah sebagai pajangan yang dapat membuat masyarakat tetap nyaman dan tidak bosan jika harus berdiam diri di rumah saja. 
Dokumentasi pelaksanaan kegiatan.

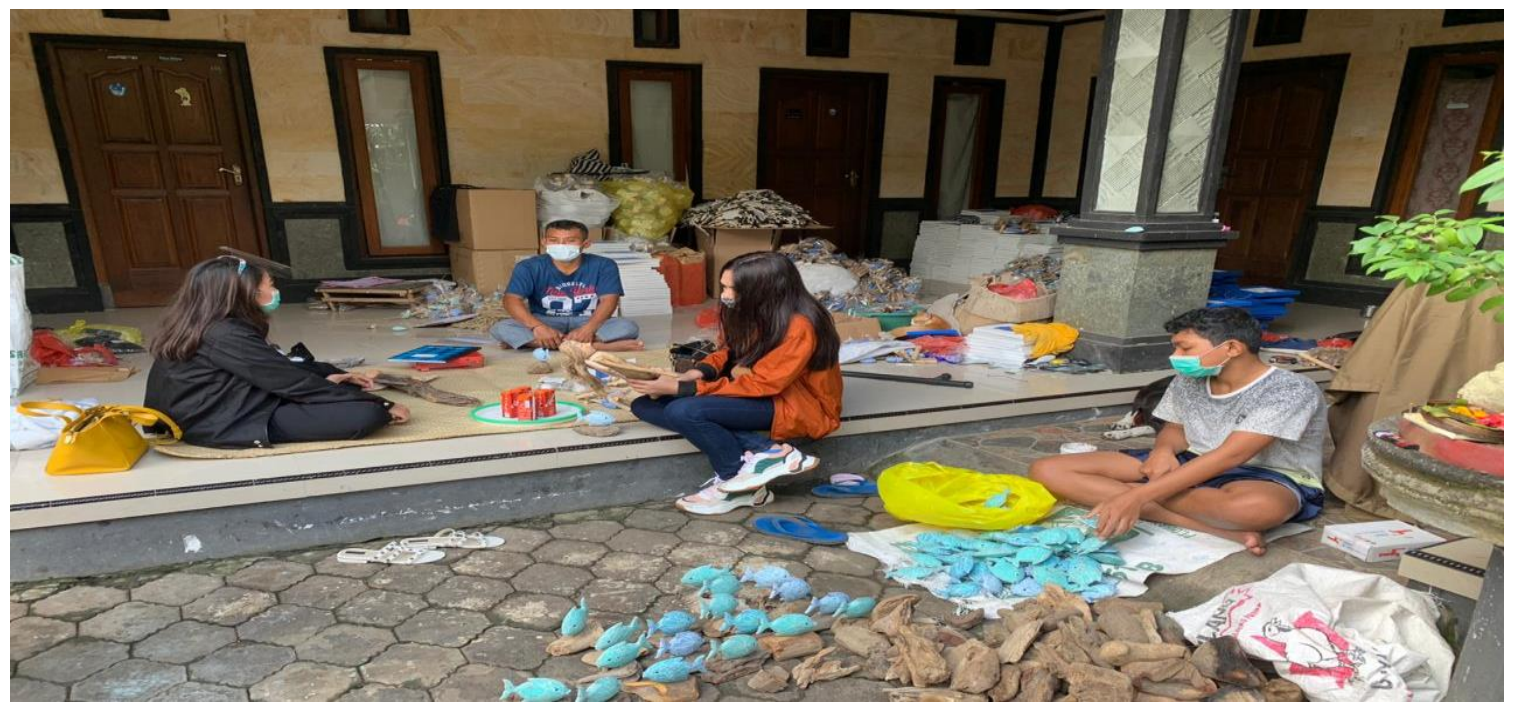

Gambar 4. Pendampingan Pelatihan Pembukuan, Pelatihan Akuntansi Manajemen, dan Pembuatan Sosial Media

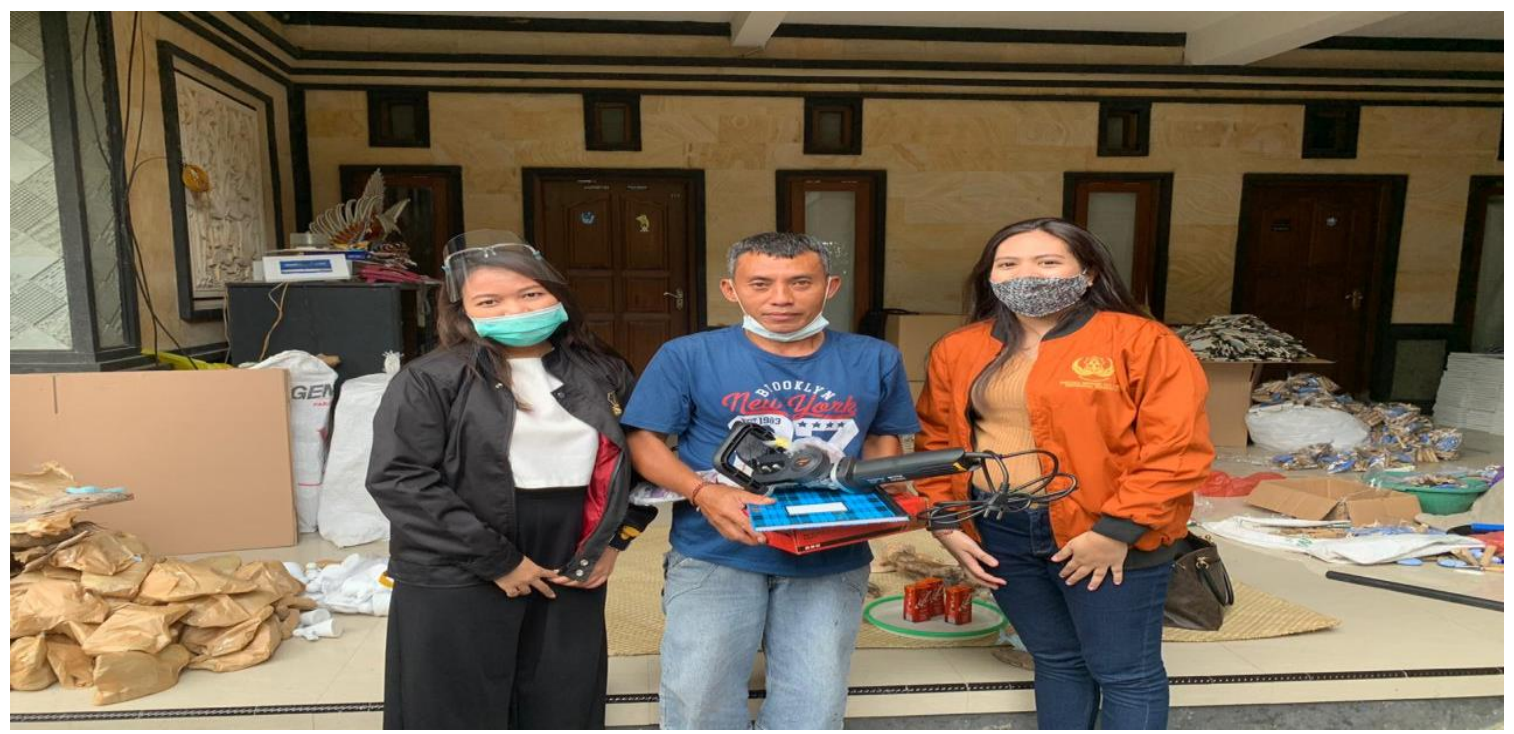

Gambar 5. Pemberian Bantuan Alat Kepada Mitra

\section{DAFTAR PUSTAKA}

https://bali-travelnews.com/2017/12/27/sampah-pantai-disulap-jadi-barang-bernilaisenil

https://brainly.co.id/tugas/14640808 